\title{
IMPLEMENTASI PEMILIHAN KEPALA DESA DI KAMPUNG IDIOT DESA SIDOHARJO KECAMATAN JAMBON KABUPATEN PONOROGO (Ditinjau berdasarkan UU No. 7 Tahun 2017 tentang Pemilu dan Fikih Siyasah)
}

\author{
Rooza Meilia Anggraini
}

\author{
Institut Agama Islam Riyadlotul Mujahidin Ngabar \\ Mayrooza@@@@@gmailcom
}

\begin{abstract}
This study aims to determine how the implementation of village head elections based on the review of Law no. 7 of 2017 concerning Elections and is also reviewed based on the rules in siyasa fiqh. Implementation of Pilkades in Sidoharjo Village is carried out like other villages in Ponorogo Regency, but in the initial stages of the implementation of pilkades, namely at the stage of determining the Voter List There are still some villagers who are seventeen years old who should have the right to vote, not registered in the Register Permanent Voters for the reason concerned are persons with disabilities who are very old and very unlikely that they will use their voting rights. Based on Law No. 7 of 2017 concerning Elections, this is not in accordance with applicable laws and regulations, because all Indonesian citizens who are seventeen years old or are married then they already have the right to vote in the General Election. However, in fiqh siyasah, this is appropriate because people with disabilities are considered incapable of the law to act on any matter. The Pilkades Election Committee's policy should give equal rights to all Villagers who have special needs or not to have the right to vote in the General Election. Keywords: Village Head Election, Law No. 7 of 2017 concerning Elections.
\end{abstract}

Keywords: Village Head Election, Law No. 7 of 2017 concerning Elections, fiqh siyasah.

\begin{abstract}
Abstrak
Penelitian ini bertujuan untuk mengetahui bagaimana pelaksanaan pemilihan Kepala Desa berdasarkan tinjauan UU No. 7 Tahun 2017 tentang Pemilu dan juga ditinjau berdasarkan kaidah-kaidah dalam fikih siyasah. Pelaksanaan Pilkades di Desa Sidoharjo dilaksanakan seperti halnya desa-desa lain di Kabupaten Ponorogo, namun pada tahap awal pelaksanaan pilkades, yaitu pada tahap penetapan Daftar Pemilih Tetap ada beberapa warga desa yang sudah berusia tujuh belas tahun yang seharusnya memiliki hak pilih, tidak terdaftar kedalam Daftar Pemilih Tetap dengan alasan yang bersangkutan adalah warga disabilitas yang sudah sangat tua dan sangat kecil kemungkinan dia akan menggunakan hak pilihnya. Berdasarkan UU No. 7 Tahun 2017 tentang Pemilu, hal tersebut tidak sesuai dengan peraturan per undangundangan yang berlaku, karena semua WNI yg sudah berusia tujuh belas tahun atau sudah menikah maka ia sudah memiliki hak pilih dalam Pemilu. Namun dalam fikih siyasah, hal tersebut sudah sesuai karena warga disabilitas dianggap tidak cakap hukum untuk bertindak atas suatu hal. Kebijakan Panitia Pemilihan Pilkades hendaknya memberikan hak yang sama terhadap seluruh Penduduk Desa baik yang berkebutuhan khusus atau tidak untuk memiliki hak memilih dalam Pemilu.
\end{abstract}

Kata Kunci: Pemilihan Kepala Desa, UU No. 7 Tahun 2017 tentang Pemilu, fikih siyasah. 


\section{Pendahuluan}

Adanya kebijakan otonomi daerah melalui Undang-Undang No.22 Tahun 1999 mengisyaratkan pemerintah dan masyarakat di daerah dipersilahkan mengurus rumah tangganya sendiri secara bertanggung jawab. Pemerintah Pusat tidak lagi menguasai/mendominasi mereka. Peran Pemerintah Pusat dalam konteks desentralisasi ini adalah melakukan supervise, memantau, mengawasi dan mengevaluasi pelaksanaan otonomi daerah. ${ }^{1}$

Sejak diberlakukannya Undang Undang tersebut, desa diberi kebebasan penuh untuk mengelola rumah tangganya, sebagaimana diuraikan dalam UU No.32 Tahun 2004 tentang Pemerintah Daerah yang menyebutkan Desa adalah kesatuan masyarakat hukum yang memiliki batas-batas wilayah yang memiliki wewenang untuk mengatur dan mengurus kepentingannya sendiri berdasarkan asal usul dan adat istiadat setempat yang diakui dan dihormati dalam sistem Pemerintahan Negara Kesatuan Republik Indonesia (NKRI). ${ }^{2}$

Sedangkan menurut Undang-Undang Republik Indonesia No 6 Tahun 2014 tentang Desa tertuang dalam Pasal I Ayat 1 bahwasannya, Desa adalah Desa dan desa adat atau yang disebut dengan nama lain, selanjutnya disebut desa adalah kesatuan masyarakat hukum yang memiliki batas-batas wilayah yang berwenang untuk mengatur dan mengurus urusan pemerintahan, kepentingan masyarakat setempat berdasarkan prakarsa masyarakat, hak asal-usul, dan/atau hak tradisional yang diakui dan dihormati dalam sisitem pemerintahan Negara Kesatuan Republik Indonesia. ${ }^{3}$

Kepala Desa merupakan salah satu unsur terpenting penyelenggara Pemerintahan Desa, karena ia merupakan pemimpin yang dipercaya masyarakat, dipilih sendiri oleh penduduk desa untuk untuk memimpin dalam kehidupan bermasyarakat demi terciptanya kehidupan yang sejahtera.

Ada beberapa istilah yang merujuk pada pengertian pemimpin. Pertama, kata

\footnotetext{
${ }^{1}$ Haris Syamsudin, Desentralisasi \& Otonomi Daerah, (Jakarta: LIPI Press, 2007), 9.

${ }^{2}$ UU No. 32 Tahun 2004 Tentang Pemerintah Daerah.

${ }^{3}$ Undang Undang No. 6 Tahun 2014 Tentang Desa.
} 
umara $>$ yang sering disebut juga dengan $u>l i l$ amri. Hal ini disebutkan dalam $\mathrm{Al}$ Quran Surat An Nisa (4) ayat 59:

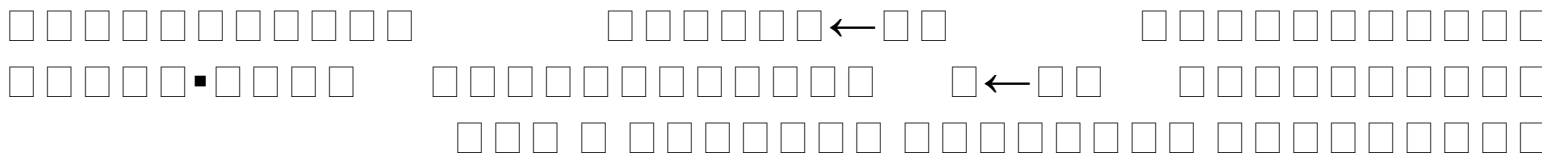

Artinya: Hai orang orang yang beriman, taatilah Allah dan taatilah Rosul, dan ulil amri di antara kalian.(An-Nisa : 59).

Pada ayat diatas, Allah ta'ala mewajibkan kita mentaati $u>$ lil amri diantara kita dan $w$ lil amri yang dimaksud adalah para Imam (Kha>lifah) yang memerintah kita. Kedua, pemimpin disebut kha>dimul ummah (pelayan ummat). Menurut istilah itu, seorang pemimpin harus menempatkan diri pada posisi sebagai pelayan rakyat. Ketiga, pemimpin dalam islam disebut juga ima $>$ mah.

Desa Sidoharjo merupakan sebuah Desa pedalaman yang terletak di Kecamatan Jambon Kabupaten Ponorogo, merupakan pemekaran dari Desa Krebet sejak 2007. Sekitar sejak tahun 1960-an lahan pertanian penduduk Desa Krebet terserang oleh hama tikus, banyak sekali warga yang mengalami gagal panen dan tidak ada lagi bahan makanan (padi) yang bisa mereka hasilkan. Oleh sebab itu warga Desa Krebet hanya bisa menkonsumsi bahan makanan yang ada, seperti ares pisang, ares pepaya, singkong, jagung, dan lain lain. Selain itu, kekeringan yang berkepanjangan menyebabkan tanah perkebunan yang mereka miliki menjadi gersang dan tandus sehingga tidak bisa ditanami selain pada musim hujan. Jadi mereka hanya bisa bercocok tanam satu kali dalam setahun dan penghasilan menjadi minim. Dan juga belum memiliki infrastruktur irigasi pertanian yang baik. Sejak saat itu, kebanyakan warga yang hamil pada tahun 60 -an melahirkan bayi-bayi yang mengalami keterburukan gizi hingga pada akhirnya sampai saat ini banyak warga Desa Krebet yang mengalami keterbelakangan mental (idiot).

Banyak faktor penyebab idiot, selain karena faktor kekurangan makanan yang menjadikan gizi minus, air yang sangat minim dan yang mereka konsumsi sehari-hari tidak mengandung zat zat penting yang diperlukan oleh tubuh seperti yodium, bahkan mengandung logam. Hal ini merupakan salah satu penyebab mereka mengalami keterbelakangan mental. Ada yang mengatakan bahwasannya selain kedua faktor tersebut, perkawinan sedarah juga merupakan salah satu penyebab 
mereka mengalami keterbelakangan mental.

Lemahnya penanganan Pemerintah Kabupaten Ponorogo membuat mereka yang tinggal diujung Desa Krebet masih belum bisa menikmati kehidupan yang layak, jarang sekali mereka tersentuh bantuan dari Pemerintah Kabupaten. Hal ini lah yang memotivasi para Pejabat Desa dan Tokoh Tokoh Desa lainnya untuk membentuk Desa baru, agar para masyarakat yang hidup di pinggiran mendapatkan pelayanan yang layak pula. Akhirnya berdirilah Desa Sidoharjo, yaitu Pemekaran dari Desa Krebet.

Berdasarkan deskripsi fenomena diatas, Penelitian ini mengkaji tentang bagaimana sistematika pemilihan Kepala Desa yang terjadi di Desa Sidoharjo Kecamatan Jambon kabupaten Ponorogo yang dikenal dengan julukan Kampung Idiot.

\section{Pemilihan Kepala Desa}

Kepala Desa merupakan unsur terpenting yang harus ada dalam suatu sistem Pemerintahan Desa selain dari pada BPD. Kepala Desa merupakan pimpinan tertinggi dalam suatu desa yang dipilih langsung oleh masyarakat desa. kepala Desa mempunyai tugas menyelenggarakan urusan pemerintahan, pembangunan, dan kemasyarakatan.,Kepala Desa adalah unsur penyelenggara pemerintahan desa yang dipilih langsung oleh penduduk desa sebagai Pemimpin Pemerintahan Desa. ${ }^{4}$

Pemilihan kepala desa dilaksanakan oleh panitia pemilihan, biaya pemilihan kepala desa dibebankan kepada APB Desa yang bersumber pada APBD kabupaten/kota. Pemilihan kepala desa dilakukan melalui tahapan penjaringan dan penyaringan bakal calon, penetapan calon, kampanye, pemungutan suara, dan penetapan calon terpilih. Calon kepala desa terpilih ditetapkan berdasarkan perolehan suara terbanyak. Calon kepala desa terpilih tersebut diatas kemudian diajukan oleh ketua panitia pemilihan kepada Badan Permusyawaratan Desa paling lama tuju hari setelah penetapan calon Kepala Desa terpilih, kemudian Badan Permusyawaratan Desa paling lama tuju hari setelah menerima laporan panitia pemilihan menyampaikan nama calon Kepala Desa terpilih kepada Bupati/Walikota.

\footnotetext{
${ }^{4}$ Peraturan Daerah Kabupaten Ponorogo No 6 Tahun 2006
} 
Bupati/Walikota menerbitkan keputusan Bupati/Walikota tentang pengesahan calon kepala desa terpilih paling lama tiga puluh hari kerja terhitung tanggal diterimanya penyampaian hasil pemilihan dari panitia pemilihan dalam bentuk keputusan Bupati/Walikota. Kepala desa terpilih dilantik oleh bupati/walikota atau pejabat yang ditunjuk paling lama 30 hari kerja terhitung tanggal penerbitan keputusan bupati/walikota. Kepala Desa memegang jabatan selama enam tahun terhitung sejak tanggal pelantikan dan dapat menjabat paling banyak tiga kali masa jabatan secara berturut-turut atau tidak secaraa berturut-turut.

\section{Pengertian Fikih Siyasah}

Fikih Siyasah berasal dari kata fiqh dan siya $>$ sah, kata figh secara leksikal berarti tahu, paham dan mengerti adalah istilah yang dipakai secara khusus dibidang hukum agama, yurisprudensi islam. Secara etimologis (bahasa) fikih adalah keterangan tentang pengertian atau paham dari maksud ucapan si pembicara, atau pemahaman yang mendalam terhadap maksud-maksud perkataan dan perbuatan.

Siyasah berasal dari kata $s a>s a$, kata ini dalam kamus $A<l$ Munjid berarti mengatur, mengurus dan memerintah. Siyasat bisa juga berarti pemerintahan dan politik, atau membuat kebijaksanaan. jadi siyasah menurut bahasa mengandung beberapa arti, yaitu mengatur, mengurus, memerintah, memimpin, membuat kebijaksanaan, pemerintahan dan politik. Artinya mengurus, mengatur, mengurus, dan membuat kebijaksanaan atas sesuatu yang bersifat politis untuk mencapai suatu tujuan adalah siyasah. ${ }^{5}$

Menurut Abdul Wahab Khallaf bahwa definisi siya $>$ sah syar'iyyah (atau fikih siyasah) adalah ,pengelolaan masalah umum bagi Negara bernuansa islam yang menjamin terealisasinya kemaslahatan dan terhindar dari kemudaratan dengn tidak melanggar ketentuan syariat dan prinsip prinsip syariat yang umum meskipun tidak sesuai dengan pendapat-pendapat para Imam Mujtahid. ${ }^{6}$ Senada dengan definisi tersebut Abdur Rahman Taj menyatakan: siya $>$ sah syar'iyyah adalah hukum-hukum yang mengatur kepentingan Negara dan mengorganisir urusan umat yang sejalan dengan jiwa syariat dan sesuai dengan dasar-dasarnya yang universal untuk merealisasikan tujuan-tujuannya yang bersifat kemasyarakatan, sekalipun hal itu

\footnotetext{
${ }^{5}$ Ibid., 23.
}

${ }^{6}$ Abdul Wahhab Khallaf, Al Siyasah Al-Syari'at, (Al Qahirat: Dar Al Anshar, 1997), 4. 
tidak ditunjukkan oleh nash-nash tafs\} ili yang juz'i dalam Al Quran da Sunnah.

Dapat disimpulkan bahwa pengertian fikih siyasah atau siya $>$ sah syar'iyah adalah ilmu yang mempelajari hal ihwal dan seluk beluk pengaturan urusan umat dan Negara dengan segala bentuk hukum, peraturan dan kebijaksanaan yang dibuat oleh pemegang kekuasaan yang sejalan dengan dasar-dasar ajaran dan ruh syariat untuk mewujudkan kemaslahatan umat. Jelasnya fikih siyasah dalam arti popular adalah ilmu tata Negara dalam Ilmu Agama Islam yang dikatagorikan kedalam pranata sosial islam. ${ }^{7}$

Objek bahasan fikih siyasah secara garis besar adalah :

1. Peraturan dan perundang-undangan Negara sebagai pedoman dan landasan idiil dalam mewujudkan kemaslahatan umat.

2. Pengorganisasian dan pengaturan untuk mewujudkan kemaslahatan.

3. Mengatur hubungan antara penguasa dan rakyat serta hak dan kewajiban maingmasing dalam usaha mencapai tujuan Negara.

\section{Tata Cara Pemilihan Pemimpin dalam Fikih Siyasah}

1. Melalui Lembaga $A<h\} l a<l-H\} a>l l w a>A>l-A>q d$

Secara harfiah arti $A<h\} l a<l-H\} a>l l w a>A>l-A>q d$ adalah orang yang dapat memutuskan dan mengikat. Sedangkan para ahli fikih siyasah mendefinisikan $A<h\} l a<l-H\} a>l l w a>A>l-A>q d$ sebagai orang yang memiliki kewenangan untuk memutuskan dan menentukan sesuatu atas nama umat (warga Negara). Atau dalam istilah kontemporer sering disebut dengan Lembaga Perwakilan Rakyat yang menampung dan menyalurkan aspirasi rakyat.

2. Melalui mekanisme penunjukan langsung oleh khalifah sebelumnya.

Dalam sistem seperti ini, Khalifah sebelumnya dapat menunjuk calon Khalifah secara langsung tanpa meminta persetujuan $A<h\} l \quad a<l-H\} a>l l$ wa $>A>l-A>q d$ sehingga mekanisme seperti ini sering disebut dengan, suksesi individual. Adapun dasar dalam pelaksanaan suksesi ini adalah suksesi pengangkatan Khalifah Umar Ibn al-Khattab oleh Khalifah Abu Bakar Ash-Shiddiq. Umat islam menyetujui kebijaksanaan Abu Bakar menunjuk Umur menjadi penggantinya. Mereka juga

\footnotetext{
${ }^{7}$ J. Suyuthi Pulungan, Fiqih Siyasah..., 26.
} 
menerima keputusan Umar membentuk Badan Musyawarah yang beranggotakan enam orang untuk memilih salah seorang dari mereka menjadi Khalifah setelah beliau wafat.

3. Melalui mekanisme Ijma' (Konsensus)

Al Haramain telah mengemukakan jika nash tentang penetapan Imam terhadap Ali telah gugur, maka cara yang dilakukan adalah sisitem pemilihan. Tapi menurut pendapatnya, ,tidak disyaratkan ijma' dalam pengangkatan Kepala Negara, tapi hal itu pasti dilakukan walaupun belum ada ijma' umat dan $A<h\} l a<l-H\} a>l l w a>A>l-A>q d$ atas pengangkatannya itu. Disini tampak ia membedakan antara pembentukan pemerintah yang didasarkan atas ijma’ dan pengangkatan kepala Negara mengabaikan ijma'.

\section{Kajian Tentang Idiot}

Amentia (Asal katanya dari: $a b=$ tanpa, mentis = mind, jiwa, mental ; amentia $=$,tanpa jiwa; sering jadi idiot). Pada kelompok amentia ini kondisi kemampuan jiwanya gagal tumbuh dengan wajar. Mental, intelegensi, perasaan dan kemauannya tidak komplit. Dalam artian: tidak berkembang secar wajar, mengalami hambatanhambatan, sehingga pertumbuhannya jadi abnormal. Kelompok amentia genetik ini terbagi atas:

\section{1) Idiocy (idiot)}

Idiot bisa dikatakan sebagai seseorang yang memiliki tingkat kecerdasan sangat rendah. ${ }^{8}$ Ada juga yang mengatakan bahwasannya idiot adalah taraf (tingkat) kecerdasan berpikir yang sangat rendah (IQ 25), atau daya pikir yang lemah sekali. ${ }^{9}$

2) Imbecility (Imbisil, orang pandir).

I.Q. nya 25-49, mereka seperti kanak-kanak yang berumur 3-7 tahun. Ukuran bobot dan tinggi badannya kurang, sering badannya cacat dan mengalami kelainan kelainan.

\footnotetext{
${ }^{8}$ Badan Pengembangan dan Pembinaan Bahasa Kementerian Pendidikan dan Kebudayaan, Kamus Bahasa Indonesia Untuk Pelajar, (Jakarta: Katalog Dalam Terbitan, 2011), 168.

${ }^{9}$ Desy Anwar, Kamus Lengkap Bahasa Indonesia, (Surabaya: Amelia, 2003), 175.
} 
3) Debil (Moron, social defect, feeble mindedness, lemah ingatan).

I.Q. nya 50-70, umur intelegensinya seperti anak-anak umur 7-16 tahun. Derajatnya ada yang rendah, medium, dan tinggi. Biasanya gejala-gejala lemah ingatan sudah tampak sebelum tahun-tahun masa sekolah. Mereka tidak mempunyai kemampuan untuk mengontrol diri, mengadakan koordinasi dan adaptasi yang wajar.

4) Moral Defectives (cacat moral)

Pada tipe ini ada defek mentalnya. Jiwa atau mentalnya sangat tidak berkembang, tumpul dan steril kehidupan afeksinya, banyak dari mereka cenderung melakukan tindakan-tindakan criminal.

Sedangkan dalam hukum islam, penyandang disabilitas (idiot) disebut ma'tuh, H\}anafiyah membedakan antara gila dan idiot, gila disebutkan dengan bahasa majnu>n yang berarti hilang akalnya, tidak bisa berfikir tentang sesuatu dan tidak sadar akan keadaannya. sedangkan idiot disebut dengan kata ma'tuh (المعته) yang berarti orang yang masih berakal, dan bisa memikirkan sebagian dari bagian yang lain, dengan sedikit pemahaman, cara berbicaranya tidak teratur. ${ }^{10}$ Hanafiyah menarik kesimpulan bahwa konsekuensi hukum bagi majnun adalah seperti $s\} o b i<y$ sedangkan untuk idiot dipersamakan dengan $s$ \}obi<y mumayyiz, artinya bahwa segala sesuatu yang diperbuat dan dilakukan dalam pengasuhan dan pengaturanya selama bermanfaat, maka diperbolehkan melakukannya tanpa memerlukan izin walinya. $^{11}$ Seperti transaksi atas hibah, diperbolehkan dan sah akadnya walaupun tanpa seizin walinya.

Berbeda lagi tentang pengampuan bagi idiot. Menurut Muhammad Muhyiddin 'Abdu Al-Hami>d bahwa idiot dalam pengampuannya dipersamakan dengan $\mathrm{s}\}$ \}obi<y goiru mumayyiz. Apabila tindakannya itu memberikan manfaat dan tidak membahayakan, maka tindakan tersebut dianggap sah walaupun tanpa seizin walinya. Apabila tindakannya tersebut membahayakan dirinya maupun orang lain maka perbuatannya dianggap tidak sah baik walinya megizinkan ataupun tanpa seizin walinya. Perbedaan antara $\mathrm{s}\}$ obi<y goiru

${ }^{10}$ Syeikh 'Abdu Rahman al-Jaziri, al-Fiqh 'ala al-Madzahibu al-Arba'a juz: 2, (Beirut,Lebanon; Daar al-Fikr AlIslamiyah, 2008), 328.

${ }^{11}$ Umar Sulaiman Al-Asyqori, Ahkamu Az-Zawaf FiDouw'i Al Kitab wa As-Sunnah, (Jordania: Daar An-Nafais,2008, cetakan keempat), 126. 
mumayyiz dan $s\} o b i<y$ mumayyiz adalah, $s\} o b i<y$ goiru mumayyiz adalah anak kecil yang umurnya belum mencapai 7 tahun belum mengerti dan memahami tentang akad, pentas\}orufan, belum cakap atas tindakannya, dan belum bisa membedakan antara yang benar dan keji. Tidak sah segala macam akad yang diucapkan maupun tindakan yang dilakukannya berkaitan atas hukum, karena tidak ada maksud dan kesengajaan dalam melakukannya. ${ }^{12} S$ \}obicy mumayyiz adalah anak kecil yang umurnya sudah mencapai umur tujuh tahun, faham dan mengerti serta bisa melaksanakan apa yang telah dia lakukan dalam akad dan sesuatu tindakan hukum, mengetahui hal-hal yang merugikan dan hal yang mempermudah atas sesuatu. ${ }^{13}$

Dalam sebuah hadist di riwayatkan oleh Imam Ahmad dan Abu Daud disebutkan: dari Aisyah r.a ia berkata: telah bersabda Rosulullah SAW:

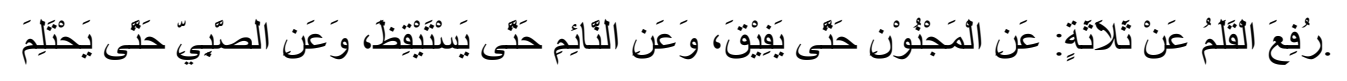

Artinya : Dihapuskan ketentuan dari tiga hal yaitu: orang tidur hingga ia bangun, anak kecil hingga ia dewasa, dan orang gila hingga ia sembuh.

Dengan demikian, orang gila, anak dibawah umur, orang yang di paksa dan terpaksa tidak dibebani pertanggungjawaban, karena dasar pertanggungjawaban mereka tidak ada. Pembebasan pertanggungjawaban ini merupakan ketetapan agama yang telah digariskan dalam Al Quran dan Hadist Nabi. Dalam riwayat lain juga disebutkan ketika Ali Bin Abi Thalib berkata kepada Umar Bin Khattab: ,tahukah engkau terhadap siapa kebaikan dan kejahatan itu dicatat dan mereka tidak bertanggungjawab terhadap apa yang dilakukannya, yaitu orang gila sampai ia waras, anak anak sampai dia baligh (puber) dan orang tidur sampai dia bangun.kemampuan bertanggungjawab di sini menunjukkan pada mampu atau tidak secara psikis bukan secara fisik. Dalam Al Quran Surat An Nur Ayat 59 juga dijelaskan:

${ }^{12}$ Muhammad Muhyiddin 'Abdu Al-Hami>d, Al-Ah\}walu As-Syahsiyyah, 427.
${ }^{13}$ Ibid., 427-428 


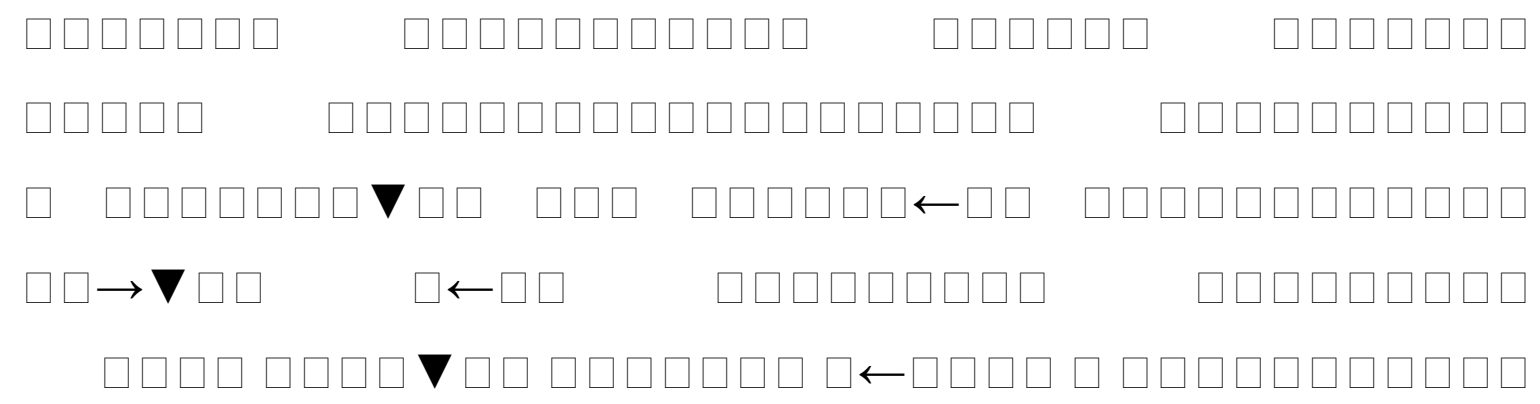

Artinya: apabila anak-anakmu telah sampai umur balig, Maka hendaklah mereka meminta izin, seperti orang-orang yang sebelum mereka meminta izin. Demikianlah Allah menjelaskan ayat-ayat-Nya. dan Allah Maha mengetahui lagi Maha Bijaksana. $^{18}$

Kelompok amentia genetic terbagi menjadi 4 golongan, yaitu: pertama, Idiocy (idiot) bisa dikatakan sebagai seseorang yang memiliki tingkat kecerdasan sangat rendah. Ada juga yang mengatakan bahwasannya idiot adalah taraf (tingkat) kecerdasan berpikir yang sangat rendah (IQ 25), atau daya pikir yang lemah sekali. Menurut data penderita keterbelakangan mental di Desa Sidoharjo, kurang lebih sekitar 24 orang yang mengalami cacat mental dan idiot. Amentia pada tahapan ini jika ditinjau berdasarkan Hukum Islam maka ia dianggap tidak sah menggunakan hak pilihnya karena ia dianggap tidak cakap hukum, dan seperti yang dijelaskan diatas, ia tidak memiliki wawasan yang luas sehingga tidak bisa membedakan mana Pemimpin yang patut dipilih, begitu juga jika ia melakukan suatu akad karena ia tidak memiliki cukup ilmu maka itu bisa membahayakan dirinya sendiri.

Kedua, Imbecility (Imbisil, orang pandir).I.Q. nya 25-49, mereka seperti kanak-kanak yang berumur 3-7 tahun. Ukuran bobot dan tinggi badannya kurang, sering badannya cacat dan mengalami kelainan kelainan, kurang lebih 107 orang yang mengalami cacat mental seperti ini. Pada tahapan ini pula ia dianggap masih belum sah jika ia menggunakan hak pilihnya, karena penderita pada tahapan ini dianggap masih seperti anak kecil atau disebut $s_{\text {fobi }}<y$ goiru mumayyiz, yaitu anak kecil yang umurnya belum mencapai 7 tahun belum mengerti dan memahami tentang akad, pentas\}orufan, belum cakap atas tindakannya, dan belum bisa membedakan antara yang benar dan keji. Tidak sah segala macam akad yang 
diucapkan maupun tindakan yang dilakukannya berkaitan atas hukum, karena tidak ada maksud dan kesengajaan dalam melakukannya.

Ketiga, Debil (Moron, social defect, feeble mindedness, lemah ingatan). I.Q. nya 50-70, umur intelegensinya seperti anak-anak umur 7-16 tahun. Derajatnya ada yang rendah, medium, dan tinggi. Pada tahapan ini penderita disibilitas baru dianggap sah hak pilihnya (berdasarkan hukum islam), karena ia sudah dianggap seperti $S\}$ obi $<y$ mumayyiz, yaitu anak kecil yang umurnya sudah mencapai umur tujuh tahun, faham dan mengerti serta bisa melaksanakan apa yang telah dia lakukan dalam akad dan sesuatu tindakan hukum, mengetahui hal-hal yang merugikan dan hal yang mempermudah atas sesuatu, dalam hal ini kurang lebih sebanyak 26 orang yang mengalami keterbelakangan mental jenis debil.

Keempat, Moral Defectives (cacat moral) Pada tipe ini ada defek mentalnya. Jiwa atau mentalnya sangat tidak berkembang, tumpul dan steril kehidupan afeksinya, banyak dari mereka cenderung melakukan tindakan-tindakan kriminal. Pada tahapan ini pula ia sudah dianggap sah menunaikan hak pilihnya, karena gangguan jiwa atau mental yang dideritanya tidak mempengaruhi pilihannya dalam memilih Pemimpin. Ia juga sudah bisa membedakan hal yang baik dan buruk dan mampu bertanggung jawab atas perbuatannya sendiri, hanya saja terkadang perlu pengawasan orang lain karena ia cenderung melakukan tindakan criminal, untuk jumlah penderita cacat moral, di Sidoharjo ini bisa dikatakan tidak ada, meskipun mereka banyak yang mengalami keterbelakangan mental namun tidak membahayakan orang lain.

Jadi, jika melihat beberapa keterangan diatas dan dikembalikan kembali pada Pemilihan Kepala Desa Sidoharjo, maka sistematika yang dijalankan khususnya dalam hal Penetapan Daftar Pemilih maka dianggap sudah sesuai dengan Undang Undang No 7 Tahun 2017 tentang Pemilu

\section{Kesimpulan}


Sistematika Pelaksanaan Pemilihan Kepala Desa di Desa Sidoharjo Kecamatan Jambon Kabupaten Ponogoro jika ditinjau berdasarkan UU No. 7 Tahun 2017 tentang Pemilu belum sepenuhnya sesuai, dalam hal penetapan Daftar Pemilih Tetap khususnya, ada beberapa warga disabilitas (kategori idiot dan imbisil) yang tidak dimasukkan kedalam Daftar Pemilih Tetap dan hal itu tidak sesuai dengan syarat-syarat Pemilih yang dijelaskan dalam UU No. 7 Tahun 2017 tentang Pemilu bahwasannya Pemilih adalah WNI yang Terdaftar sebagai penduduk desa yang bersangkutan sekurang-kurangnya enam bulan dengan tidak terputus-putus pada saat dimulainya pendaftaran pemilihan, Sudah berumur tujuh belas tahun dan atau sudah pernah menikah pada saat dimulainya pendaftaran pemilih, Tidak dicabut hak pilihnya berdasarkan keputusan Pengadilan yang mempunyai kekuatan hukum tetap.

Jadi, dari persyaratan diatas jelas ada penyimpangan dengan fakta yang terjadi di lapangan, karena tidak semua warga disabilitas dimasukkan kedalam Daftar Pemilih Tetap sehingga mereka tidak bisa menggunakan hak politiknya

sebagai Warga Negara Indonesia dalam hal Pemilihan Kepala Desa, padahal telah jelas dipaparkan dalam beberapa konverensi maupun peraturan perundang-undangan bahwasannya penyandang disabilitas tetap memperoleh hak politik yang sama layaknya Warga Negara Indonesia yang normal lainnya.

Berdasarakan Hukum Islam, sitematika Pilkades yang dilaksanakan di Desa Sidoharjo Kecamatan Jambon Kabupaten Ponorogo sudah sesuai dengan kaidah hukum islam. Karena tidak semua warga disabilitas dimasukkan kedalam Daftar Pemilih Tetap karena mereka dianggap tidak memenuhi syarat-syarat sebagai dewan pemilih, yaitu tidak memiliki wawasan yang mampu membuatnya sanggup membedakan hal yang baik dan buruk dan belum cukup adil dalam melakukan suatu perbuatan. Hanya sebagian warga disabilitas saja yang didaftar kedalam DPT tergantung pada tingkatan amentia yang dideritanya, dan menurut tinjauan hukum islam hal tersebut sudah sesuai, karena memang penyandang disabilitas yang ada di Desa Sidoharjo ini beraneka ragam tingkatannya. Jika hanya Tuna Netra maupun Tuna Rungu mereka tetap didaftar sebagai Daftar Pemilih Tetap. Hanya warga disabilitas yang sudah sangat tua (lumpuh total) dan tidak 
memungkinkan jika dia memenuhi hak politiknya untuk memilih Kepala Desa, maka ia tidak ditetapkan kedalam Daftar Pemilih Tetap, karena mereka dianggap tidak mampu mempertanggungjawabkan perbuatannya sendiri dan akad yang dilaksanakannya dianggap tidak sah.

\section{Saran}

Berdasarkan kesimpulan diatas diharapkan agar Pejabat Pemerintahan di Desa Sidoharjo Kecamatan Jambon Kabupaten Ponorogo khususnya Panitia Pemilihan Kepala Desa memberikan hak politik yang sama kepada seluruh penyandang disabilitas yang sudah cukup umur dan sudah memiliki hak pilih, meskipun kemungkinan besar mereka tidak menggunakan hak pilihnya, tapi dengan seperti itu mereka beranggapan bahwa mereka memiliki hak yang sama sebagai Warga Negara Indonesia pada umumnya. Selain itu, demi terwujudnya demokrasi di desa, maka perlu disediakan peralatan untuk Pemilihan Kepala Desa, baik kertas suara, bilik suara, maupun peralatan yang lainnya yang dikhususkan bagi warga disabilitas untuk menunjang kesuksesan pesta demokrasi desa yaitu dengan terciptanya Pemilihan Umum yang langsung, umum, bebas, rahasia, jujur, dan adil. 
Al-Asyqori, Umar Sulaiman. Ahka>mu Az-Zawa ji fi d\}ouw'i Al-Kitab wa As-Sunnah. Jordania: Daar An-Nafa $>$ is, 2008, cetakan keempat.

Anwar, Desi. Kamus Lengkap Bahasa Indonesia. Surabaya: Amelia, 2003.

Badan Pengembangan dan Pembinaan Bahasa Kementerian Pendidikan dan Kebudayaan. Kamus Bahasa Indonesia Untuk Pelajar. Jakarta: Katalog Dalam Terbitan, 2011.

Khallaf, Abdul Wahhab. Al Siyasah Al-Syari'at. Al Qahirat: Dar Al Anshar, 1997.

Kartono, Kartini. Psikologi Abnormal dan Abnolmalitas Seksual . Bandung: Mandar Maju, 2009.

Pulungan, J. Suyuthi. Fiqih Siyasah. Jakarta: Raja Grafindo, 1997.

Syamsudin, Haris. Desentralisasi \& Otonomi Daerah. Jakarta: LIPI Press, 2007.

Departemen Agama RI. Al-Qur'an Terjemahnya. Bandung;Diponegoro, 2005.

Undang Undang RI No. 7 Tahun 2017 tentang Pemilu.

Undang Undang RI No. 6 Tahun 2014 tentang Desa.

Undang Undang No. 32 Tahun 2004 Tentang Pemerintah Daerah.

Peraturan Daerah Kabupaten Ponorogo No.06 Tahun 2006 Tentang Tata Cara Pencalonan, Pemilihan, Pengangkatan, Pelantikan, dan Pemberhentian Kepala Desa. 